\title{
ANTIOXIDANT ACTIVITY TEST OF LIDAH MERTUA (SANSEVIERIA TRIFASCIATA P.) LEAVES EXTRACT USING 1,1-DIPHENIL-2-PIKRILHIDRAZIL
}

\author{
Rihanah \& Minarni Rama Jura \\ Jurusan Pendidikan MIPA \\ Fakultas Keguruan dan IImu Pendidikan Universitas Tadulako Palu
}

\begin{abstract}
Antioxidant activity test of lidah mertua (Sansevieria trifasciata P.) leaves extract using 1,1-diphenil2-picrylhydrazyl has been carried out. The purpose of this study was to determine the antioxidant activity of ethanol extracts of old and young leaves of lidah mertua (Sansevieria trifasciata P.). The radical concentration of 1,1-diphenil-2-picrylhydrazyl (DPPH) after the addition of ethanol extracts of old and young leaves of lidah mertua was determined using a UV-Vis spectrophotometer. The concentrations used in the ethanol extracts of old and young leaves of lidah mertua were 20 ppm, 40 ppm, 60 ppm, 80 ppm and $100 \mathrm{ppm}$. The $I C_{50}$ values obtained of ethanol extracts of old and young leaves of lidah mertua were $131.336 \mathrm{ppm}$ and $144.568 \mathrm{ppm}$ respectively, while $I_{50}$ value of vitamin $C$ as a comparison was $65.433 \mathrm{ppm}$. It can be seen that the antioxidant ethanol extracts of old and young leaves of lidah mertua are moderate compared to vitamin $C$.
\end{abstract}

Keywords: Lidah mertua, antioxidant, DPPH, UV-Vis spectrophotometer.

\section{PENDAHULUAN}

Radikal bebas merupakan atom ataupun molekul yang elektron valensinya tidak berpasangan pada orbital terluarnya yang sangat reaktif dan kurang stabil. Atom tersebut berupa atom hidrogen, logam-logam transisi dan molekul oksigen. Untuk mencapai kestabilan, maka radikal bebas memerlukan elektron di sekitarnya untuk bereaksi memperoleh pasangan elektron (Masrifah, dkk. 2017). Reaksi ini jika berada dalam tubuh akan terjadi secara terus-menerus, dan jika tidak segera dihentikan, maka akan merusak sel maupun jaringan yang ada di dalam tubuh manusia (Nasution \& Rahma, 2014). Kerusakan sel mampu mengakibatkan penuaan dan berbagai penyakit seperti kanker, penderita diabetes, rheumatoid arthritis, kardiovaskular penyakit, peradangan kronis, dan stroke (Shanmugam, dkk. 2018).

Antioksidan dibutuhkan untuk menangkal radikal bebas. Antioksidan berfungsi mengatasi atau menetralisir radikal bebas, sehingga diharapkan dengan pemberian antioksidan tersebut reaksi radikal bebas dapat dihambat, serta dapat mencegah kerusakan sel tubuh manusia dari timbulnya penyakit degeneratif (Kosasih dkk., 2006). Antioksidan dapat diperoleh dari asupan makanan yang banyak mengandung vitamin $C$, vitamin $E$, dan beta karoten, serta senyawa fenolik (Prakash, et al. 2001). Antioksidan alami mampu melindungi tubuh terhadap kerusakan yang disebabkan oleh spesies oksigen reaktif, menghambat terjadinya penyakit degeneratif dan mampu menghambat peroksidase lipid pada makanan (Hasnaeni \& Aminah, 2019). Pereaksi yang digunakan untuk menguji aktioksidan yaitu 1,1-diphenil-2-pikrilhidrazil (DPPH). DPPH memberikan informasi reaktivitas terhadap senyawa yang akan diuji dengan suatu radikal bebas. Senyawa yang bereaksi sebagai penangkal radikal bebas akan mereduksi $\mathrm{DPPH}$, diamati dengan adanya perubahan warna DPPH, dari ungu menjadi kuning ketika elektron ganjil dari radikal bebas. DPPH telah berpasangan dengan hidrogen dari senyawa penangkal radikal bebas, akan membentuk DPPH-H tereduksi (Molyneux, 2004).

Indonesia memiliki keanekaragaman tanaman, salah satunya adalah tumbuhan lidah mertua. Tumbuhan lidah mertua (Sansevieria trifasciata P.) adalah tumbuhan yang paling banyak ditemukan sebagai tanaman hias rumah. Satu tanaman lidah mertua dewasa yang berdaun 4-5 helai dapat menyegarkan udara dalam ruangan seluas $20 \mathrm{~m}^{2}$ (Ifada, dkk. 2016). Zat aktif yang terkandung dalam ekstrak daun lidah mertua dapat menghambat pertumbuhan bakteri yaitu saponin, fenol, dan flavonoid, dimana senyawa-senyawa ini memiliki efek antiseptik, anti-inflamasi, dan anti kanker (Lombogia, dkk. 2016). Adanya beberapa senyawa tersebut dalam tumbuhan lidah mertua (Sansevieria trifasciata P.), yang menginspirasi peneliti untuk melakukan penelitian tentang aktivitas antioksidan dalam daun tua dan daun muda tumbuhan lidah mertua, yang diduga mempunyai kemampuan sebagai antioksidan untuk menangkal radikal bebas. Pada penelitian ini, peneliti menggunakan daun tua dan daun muda tumbuhan lidah mertua (Sansevieria trifasciata P.) yang terdapat di Kelurahan Tondo, Kecamatan Mantikulore, Kota Palu, Provinsi Sulawesi Tengah.

\section{ALAT DAN BAHAN}

Peralatan yang digunakan yaitu neraca analitik, neraca digital, pipet mikro, blender, corong pisah, corong buncher, ayakan 80 mesh, kuvet, seperangkat alat rotary vacum evaporator, spektrofotometer UV-Vis PG instrument Ltd, labu takar, penangas air, dan peralatan gelas yang umum di laboratorium. 
Bahan yang digunakan yaitu daun muda lidah mertua, daun tua lidah mertua, etanol absolute, reagen dragendorf, aquadest, aluminium foil, kertas saring, larutan $\mathrm{FeCl}_{3} 5 \%$, aquadest, serbuk $\mathrm{Mg}, \mathrm{HCl}$ pekat, DPPH, dan vitamin C (Merck).

\section{METODE}

Penelitian ini merupakan penelitian eksperimen yang dilaksanakan pada bulan Agustus 2019 sampai Januari 2020 di Laboratorium Penelitian Jurusan Kimia Fakultas Matematika dan IImu Pengetahuan Alam Universitas Tadulako, Palu.

\section{Preparasi Sampel}

Preparasi sampel yang dilakukan pada penelitian ini meliputi beberapa tahap sebagai berikut:

1) Daun tua dan daun muda tumbuhan lidah mertua dipetik.

2) Dicuci dengan air mengalir hingga bersih, kemudian ditiriskan.

3) Daun tua dan daun muda tumbuhan lidah mertua dipotong kecil-kecil.

4) Potongan daun tua dan daun muda tumbuhan lidah mertua tersebut dikeringkan dengan cara dianginkan selama beberapa hari.

5) Potongan daun yang sudah kering diblender kemudian diayak menggunakan ayakan 80 mesh.

\section{Ekstraksi dengan Etanol}

Ekstrak daun tua dan daun muda tumbuhan lidah mertua masing-masing ditimbang sebanyak 3 gram menggunakan neraca digital, kemudian dimasukkan ke dalam erlenmyer $100 \mathrm{~mL}$, lalu ditambahkan $50 \mathrm{~mL}$ etanol absolut, kemudian campuran dikocok selama 1 jam, kemudian disaring dengan corong pisah. Ampas yang diperoleh ditambahkan $50 \mathrm{~mL}$ etanol absolut, campuran kembali dikocok selama 1 jam. Kemudian disaring dengan corong pisah, filtrat yang diperoleh dikumpulkan dan dipekatkan dengan rotary vakum evaporator.

\section{Uji Fitokimia}

Uji fitokimia yang dilakukan pada penelitian ini mengikuti prosedur yang telah dilakukan oleh peneliti sebelumnya Susana dkk (2018).

1) Uji Flavonoid

Ekstrak daun tua dan daun muda tumbuhan lidah mertua masing-masing diukur sebanyak 2 $\mathrm{mL}$ menggunakan gelas ukur, lalu dimasukkan ke dalam tabung reaksi, ditambahkan 0,5 gram serbuk $\mathrm{Mg}$ dan 10 tetes $\mathrm{HCl}$ pekat. Jika terbentuk larutan berwarna kuning, jingga, atau merah menunjukkan reaksi positif adanya flavonoid.

2) Uji Saponin

Ekstrak daun tua dan daun muda tumbuhan lidah mertua masing-masing diukur sebanyak 2 $\mathrm{mL}$ menggunakan gelas ukur, lalu dimasukkan ke dalam tabung reaksi, ditambahkan dengan 2-4 tetes aquades panas bersuhu $70^{\circ} \mathrm{C}$. Setelah itu, campuran dikocok sampai muncul buih, dan didiamkan selama 10 menit. Terbentuknya buih tersebut sebagai indikator reaksi positif adanya saponin.

\section{3) Uji Alkaloid}

Ekstrak daun tua dan daun muda tumbuhan lidah mertua masing-masing diukur sebanyak 2 $\mathrm{mL}$ menggunakan gelas ukur, lalu dimasukkan ke dalam tabung reaksi, lalu ditambahkan 2-3 tetes pereaksi dragendorf. Bila bereaksi positif akan menghasilkan endapan merah jingga.

4) Uji Tanin

Ekstrak daun tua dan daun muda tumbuhan lidah mertua masing-masing diukur sebanyak 2 $\mathrm{mL}$ menggunakan gelas ukur, lalu dimasukkan ke dalam tabung reaksi, kemudian ditambahkan $\mathrm{FeCl}_{3} 5 \%$. Terbentuk warna hijau pekat menunjukkan reaksi positif adanya tanin.

\section{Uji Aktivitas Antioksidan}

Ekstrak daun tua dan daun muda tumbuhan lidah mertua masing-masing ditimbang sebanyak $10 \mathrm{mg}$ menggunakan neraca analitik. Selanjutnya, dimasukkan ke dalam labu ukur $10 \mathrm{~mL}$, kemudian dilarutkan dengan etanol dan dicukupkan volumenya sampai tanda batas sehingga diperoleh 1000 ppm. Selanjutnya diambil masingmasing larutan tersebut sebanyak $0,2 \mathrm{~mL}, 0,4 \mathrm{~mL}$, $0,6 \mathrm{~mL}, 0,8 \mathrm{~mL}$ dan $1 \mathrm{~mL}$, diencerkan kembali dengan etanol dalam labu ukur $10 \mathrm{~mL}$, sehingga diperoleh larutan ekstrak dengan konsentrasi $(20$, 40, 60, 80 dan 100 ppm).

Vitamin $C$ sebagai pembanding ditimbang sebanyak $10 \mathrm{mg}$, dimasukkan ke dalam labu ukur $10 \mathrm{~mL}$, kemudian dilarutkan dengan etanol, dan dicukupkan volumenya sampai tanda batas sehingga diperoleh 1000 ppm. Selanjutnya ambil masing-masing larutan tersebut sebanyak $0,2 \mathrm{~mL}$, $0,4 \mathrm{~mL}, 0,6 \mathrm{~mL}, 0,8 \mathrm{~mL}$, dan $1 \mathrm{~mL}$, diencerkan kembali dengan etanol dalam labu ukur $10 \mathrm{~mL}$ sehingga diperoleh larutan ekstrak dengan konsentrasi (20, 40, 60, 80 dan 100 ppm).

Penentuan aktivitas antioksidan pada masingmasing konsentrasi diambil sebanyak $0,5 \mathrm{~mL}$ larutan sampel dengan pipet mikro, dan dimasukkan ke dalam vial, ditambahkan $3,5 \mathrm{~mL}$ larutan DPPH $50 \mathrm{mM}$. Campuran dihomogenkan, kemudian ditutup dengan aluminium foil dan dibiarkan selama 30 menit di tempat gelap, serapan diukur dengan spektrofotometer UV-Vis pada panjang gelombang $517 \mathrm{~nm}$. Aktivitas antioksidan sampel ditentukan oleh besarnya hambatan radikal DPPH melalui perhitungan persentase inhibisi serapan DPPH dengan menggunakan rumus berikut:

$\%$ penghamba $\tan =\frac{(\text { absblanko }- \text { abssampel })}{\text { absblanko }} \times 100$ 
Keterangan: Absblanko adalah absorban DPPH $50 \mathrm{mM}$ dan AbsSampel adalah absorbansi Sampel Uji (Nurhaeni dkk. 2019).

Hasil perhitungan yang diperoleh dimasukkan ke dalam persamaan regresi dengan konsentrasi ekstrak (ppm) pada sumbu $x$ dan nilai \% inhibisi (antioksidan) pada sumbu y untuk menentukan $\mathrm{IC}_{50}$ dengan persamaan:

$$
\begin{aligned}
& Y=a x+b \\
& 50=a x+b \\
& x\left(I C_{50}\right)=\frac{50-b}{a}
\end{aligned}
$$

(Hestiningtyas, dkk. 2019).

\section{HASIL DAN PEMBAHASAN Ekstraksi dengan Etanol}

Metode ekstraksi yang digunakan adalah maserasi (ekstraksi dingin) untuk mencegah rusaknya senyawa-senyawa kimia yang tidak tahan terhadap pemanasan khususnya flavonoid. Prinsip dari ekstraksi ini yaitu cairan masuk ke dalam rongga sel yang mengandung zat aktif dan akan larut ke dalam pelarut karena terdapat perbedaan konsentrasi antara larutan zat aktif didalam sel dengan diluar sel, zat aktif akan berdifusi keluar sel (Estikawati \& Lindawati, 2019). Ekstrak daun tua dan daun muda tumbuhan lidah mertua masing-masing ditimbang sebanyak 3 gram menggunakan neraca digital, kemudian dimasukkan ke dalam labu ukur $100 \mathrm{~mL}$. Sampel diekstraksi dengan etanol absolut sebanyak $50 \mathrm{~mL}$ dengan pengocokan selama 1 jam. Tujuan penggunaan etanol sebagai pelarut karena etanol lebih mudah menembus membran sel, melarutkan senyawa metabolit sekunder dari bahan tumbuhan dan mudah diuapkan. Pemilihan pelarut etanol ini berdasarkan like dissolve like, artinya pelarut polar akan melarutkan senyawa polar dan pelarut non polar akan melarutkan senyawa non polar (Sastrohamidjojo, 2016). Pengocokan dilakukan dengan tujuan untuk menghomogenkan ekstrak daun tua dan daun muda tanaman lidah mertua dengan etanol, hingga diperoleh hasil ekstrak berwarna hijau muda untuk ekstrak daun tua, dan berwarna hijau tua untuk ektsrak daun muda tumbuhan lidah mertua (Sagita, dkk. 2018).

Ekstrak daun tua dan daun muda tumbuhan lidah mertua masing-masing disaring dengan corong pisah, untuk memisahkan filtrat dan residu. Ampas yang diperoleh ditambahkan $50 \mathrm{~mL}$ etanol $80 \%$. Campuran dimaserasi dengan pengocokan selama 1 jam, kemudian disaring dengan corong pisah, sehingga diperoleh filtrat. Filtrat yang diperoleh dikumpulkan dan dipekatkan dengan rotary evaporator. Tujuan dilakukan pemekatan yaitu untuk memisahkan dan menguapkan antara pelarut dengan ekstrak, sehingga diperoleh ekstrak kental daun tua dan daun muda tumbuhan lidah mertua, kemudian dikeringkan. Sebanyak 10 mg ekstrak daun tua dan daun muda tumbuhan lidah mertua masing-masing dimasukkan ke dalam labu ukur $10 \mathrm{~mL}$. Ditambahkan $10 \mathrm{~mL}$ etanol untuk melarutkan residu, lalu diaduk untuk mempercepat proses pelarutan residu, hingga diperoleh warna kekuningan pada ekstrak daun tua dan daun muda tumbuhan lidah mertua.

\section{Uji Fitokimia}

Uji fitokimia bertujuan untuk mengidentifikasi senyawa metabolit sekunder. Senyawa-senyawa tersebut dapat diidentifikasi dengan pereaksi yang mampu memberikan ciri khas dari setiap golongan dari metabolit sekunder (Chezem \& Clay, 2016).

Tabel 1. Hasil uji fitokimia ekstrak daun tua tumbuhan lidah mertua

\begin{tabular}{lc}
\multicolumn{1}{c}{ Perlakuan } & Hasil Pengamatan \\
\hline \multicolumn{1}{c}{ Uji Flavonoid } & $(+)$ \\
Uji Alkaloid & $(+)$ \\
Uji Saponin & $(+)$ \\
Uji Tanin & $(-)$ \\
\hline
\end{tabular}

Tabel 2. Hasil uji fitokimia ekstrak daun muda tumbuhan lidah mertua

\begin{tabular}{lc}
\hline \multicolumn{1}{c}{ Perlakuan } & Hasil Pengamatan \\
\hline Uji Flavonoid & $(+)$ \\
Uji Alkaloid & $(+)$ \\
Uji Saponin & $(+)$ \\
Uji Tanin & $(-)$ \\
\hline
\end{tabular}

Keterangan: (+) adalah hasil positif dan (-) adalah hasil negatif.

Uji flavonoid menunjukkan hasil positif dengan adanya perubahan warna merah dan terdapat endapan merah jingga. Senyawa-senyawa polifenol memiliki aktivitas sebagai antioksidan dengan menghambat reaksi oksidasi dengan cara menangkap radikal bebas. Gugus fenol dalam flavonoid akan menyumbangkan 1 elektron pada radikal bebas yang tidak berpasangan sehingga radikal bebas itu menjadi stabil kembali (Arifin \& Ibrahim, 2018).

Uji saponin menunjukkan hasil positif dengan adanya buih setelah pengocokan pada ekstrak daun tua dan daun muda tumbuhan lidah mertua. Saponin adalah senyawa aktif permukaan yang kuat, menimbulkan buih jika dikocok dalam air, dan pada konsentrasi yang rendah sering 
menyebabkan hemolysis sel darah merah (Robinson, 1995). Buih yang ditimbulkan saponin disebabkan karena saponin mengandung senyawa yang sebagian larut dalam pelarut air (hidrofilik), dan senyawa yang larut dalam pelarut non polar (hidrofobik) surfaktan yang dapat menurunkan tegangan permukaan (Nurhaeni dkk. 2019).

Uji alkaloid menunjukkan hasil positif dengan adanya endapan merah jingga, saat penambahan pereaksi dragendorf pada ekstrak daun tua dan daun muda tumbuhan lidah mertua. Menurut Achmad (1986), hasil positif yang diperoleh pada uji alkaloid terlihat pada endapan yang terbentuk. Pereaksi dragendorf akan bereaksi dengan alkaloid, membentuk endapan berwarna merah jingga dimana endapan tersebut adalah kalium alkaloid.

\section{Uji Aktivitas Antioksidan}

Aktivitas antioksidan ekstrak daun tua dan daun muda tumbuhan lidah mertua diuji dengan mereaksikan sampel dan larutan DPPH, dan diukur pada panjang gelombang $517 \mathrm{~nm}$, yang merupakan panjang gelombang maksimum DPPH. Panjang gelombang maksimum ini memberikan serapan paling maksimal dari larutan uji, dan memberikan kepekaan paling besar. Metode ini dipilih karena mudah, cepat, sederhana, dan mempunyai tingkat sensitivitas tinggi, serta dapat menganalisa sampel dalam jangka waktu singkat (Widiastuti, 2016).

Pengujian aktivitas antioksidan dilakukan dengan penentuan persentase inhibisi ekstrak daun tua dan daun muda tumbuhan lidah mertua pada masing-masing konsentrasi, yaitu $20 \mathrm{ppm}$, 40 ppm, 50 ppm, 80 ppm, dan 100 ppm. Nilai absorbansi ekstrak daun tua dan daun muda tumbuhan lidah mertua, semakin berkurang dengan meningkatnya konsentrasi. Hal ini terjadi karena adanya reduksi radikal DPPH oleh antioksidan, dimana semakin tinggi konsentrasi ekstrak daun tua dan daun muda tumbuhan lidah mertua, maka semakin besar aktivitas antioksidannya, dan menyebabkan absorbansinya semakin berkurang (Molyneux, 2004).

Tabel 3. Hasil pengukuran absorbansi DPPH pada ekstrak daun tua dan daun muda tumbuhan lidah mertua

\begin{tabular}{ccc}
\hline \multirow{2}{*}{ Konsentrasi $(\mathrm{ppm})$} & \multicolumn{2}{c}{ Absorbansi (A) } \\
& Ekstrak daun tua lidah mertua & Ekstrak daun muda lidah mertua \\
\hline 20 & 0,706 & 0,713 \\
60 & 0,684 & 0,685 \\
80 & 0,631 & 0,649 \\
100 & 0,527 & 0,567 \\
\hline
\end{tabular}

\section{Absorbansi DPPH $=0,826$}

Hasil penelitian nilai absorbansi ekstrak daun tua dan daun muda tumbuhan lidah mertua dapat dilihat pada gambar 1 dan 2.

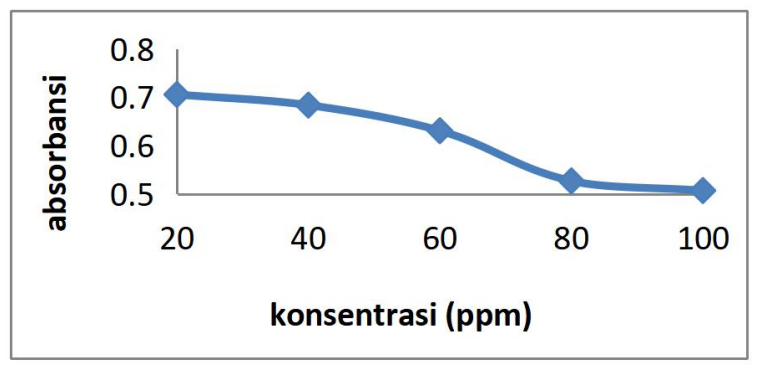

Gambar 1. Kurva Hubungan konsentrasi (ppm) ekstrak daun tua tumbuhan lidah mertua dengan nilai absorbansi (A) 


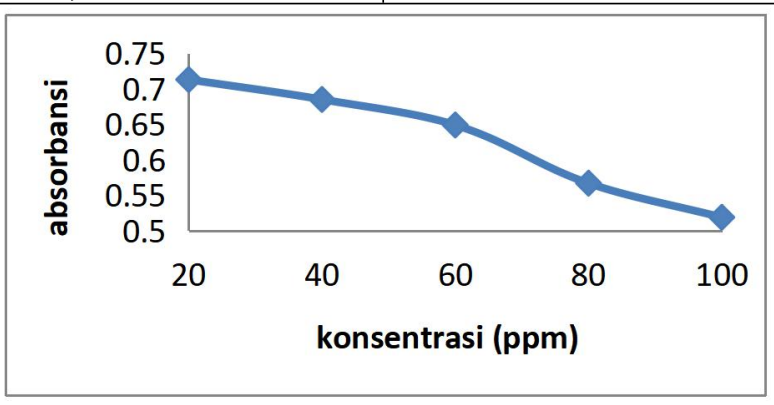

Gambar 2. Kurva Hubungan konsentrasi (ppm) ekstrak daun muda tumbuhan lidah mertua dengan nilai absorbansi (A)

Nilai $\mathrm{IC}_{50}$ pada masing-masing ekstrak daun tua lidah mertua dan daun muda tumbuhan lidah mertua ditentukan dengan menggunakan persamaan regresi linear dari kurva hubungan konsentrasi sampel terhadap persen inhibisi yang disajikan pada Gambar 3 dan 4.

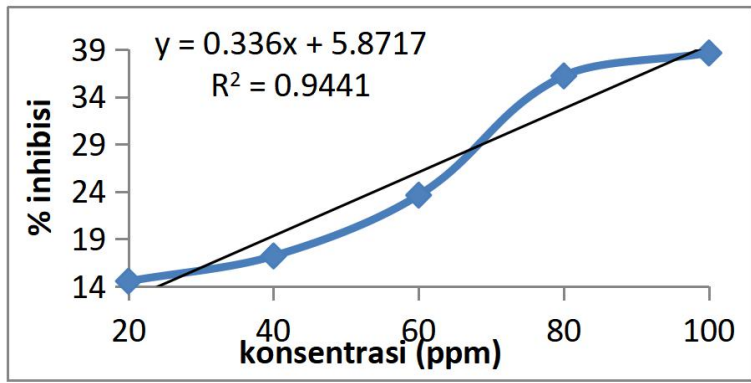

Gambar 3. Kurva hubungan konsentrasi ( $\mathrm{ppm}$ ) ekstrak daun tua tumbuhan lidah mertua dengan persentase inhibisi (\%)

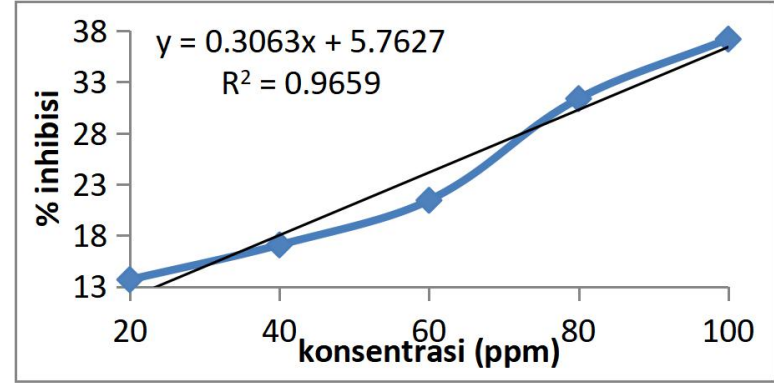

Gambar 4. Kurva hubungan konsentrasi (ppm) ekstrak daun muda tumbuhan lidah mertua dengan persentase inhibisi (\%)

Kurva pada Gambar 3. diperoleh nilai untuk regresi linear $y=0,336 x+5,8717$ untuk ekstrak daun tua tumbuhan lidah mertua dan Gambar 4. diperoleh nilai untuk regresi linear $y=0,3063 x+5,7627$. Dari data tersebut menunjukkan bahwa semakin besar konsentrasi ekstrak daun tua dan daun muda tumbuhan lidah mertua, semakin besar pula persentase penghambat radikal DPPH. Nilai persentase penghambatan tertinggi masing-masing untuk ekstrak daun tua dan daun muda tumbuhan lidah mertua yaitu $38,619 \%$ dan $31,355 \%$. Nilai $I_{50}$ secara berturut-turut untuk ekstrak daun tua lidah mertua dan daun muda lidah mertua yaitu 131,336 ppm dan 144, 568 ppm.

Ekstrak daun tua tumbuhan lidah mertua mempunyai aktivitas antioksidan lebih kuat dibandingkan dengan ekstrak daun muda tumbuhan lidah mertua. Data absorbansi yang diperoleh menunjukkan bahwa semakin tua umur daun, maka semakin kecil nilai absorbansinya. Ekstrak daun tua tumbuhan lidah mertua memiliki senyawa flavonoid yang lebih banyak dibandingkan ekstrak daun muda tumbuhan lidah mertua, semakin banyak komponen polifenol dalam flavonoid maka aktivitas antioksidan semakin tinggi (Wandita \& Musfiroh, 2018). Kandungan polifenol yang didapat pada saat proses ekstraksi dipengaruhi oleh pelarut yang digunakan (Marliani dkk., 2017).

Vitamin C (asam askorbat) dalam pengujian ini sebagai pembanding atas aktivitas antioksidan dengan masing-masing konsentrasi $20,40,60,80$ dan $100 \mathrm{ppm}$. Semakin besar konsentrasi vitamin C maka semakin besar pula persentase penghambatan radikal bebas DPPH yang terjadi. Hal ini disebabkan karena semakin besar konsentrasi vitamin $\mathrm{C}$, maka semakin banyak partikel-partikel yang dapat mengoksidasi partikelpartikel dari radikal bebas DPPH yang ada 
(Mariani, dkk. 2018). Uji aktivitas antioksidan terhadap vitamin C dapat ditunjukkan pada Gambar 5.

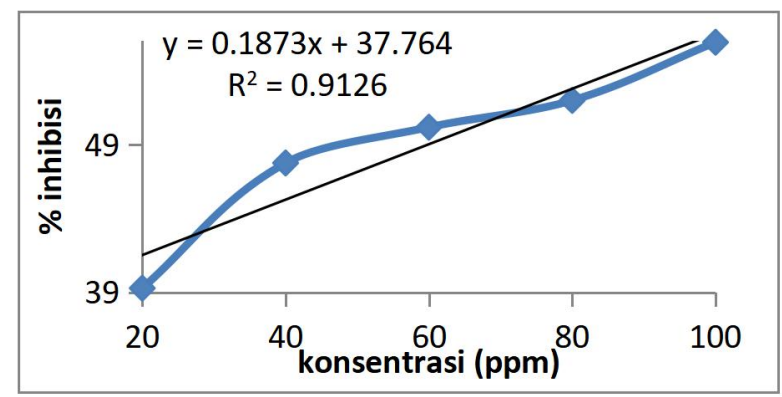

Gambar 5. Kurva hubungan konsentrasi (ppm) vitamin C dengan nilai absorbansi (A)

Nilai absorbansi pada uji antioksidan vitamin C, diperoleh persentase penghambatan radikal bebas DPPH, seperti terlihat pada Gambar 5 menunjukkan hubungan konsentrasi vitamin C dengan persentase penghambatan radikal bebas DPPH. Semakin besar konsentrasi vitamin C, maka semakin besar pula persentase penghambatan radikal bebas DPPH. Hal ini dikarenakan semakin besar konsentrasi vitamin C, maka semakin banyak partikel yang dapat mengoksidasi partikel dari radikal bebas DPPH yang ada (Moleynux, 2004). Nilai IC 50 pada vitamin C ditentukan dengan menggunakan persamaan regresi linear dari kurva hubungan konsentrasi sampel terhadap persen inhibisi yang disajikan pada Gambar 6.

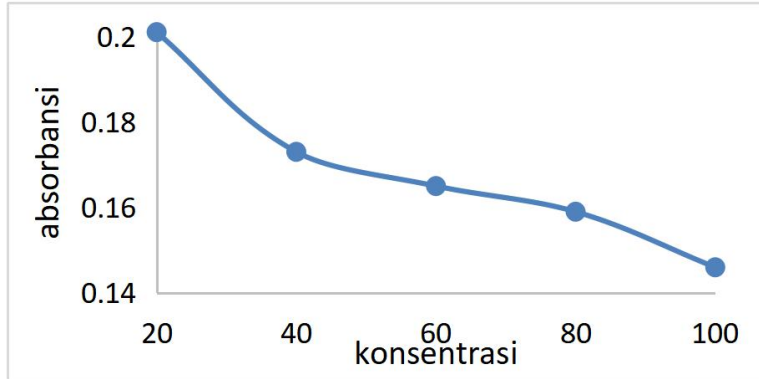

Gambar 6. Kurva hubungan konsentrasi (ppm) asam askorbat dengan persentase inhibisi (\%)

Nilai $\mathrm{IC}_{50}$ pada pembanding vitamin $\mathrm{C}$ jika dibandingkan dengan nilai $\mathrm{IC}_{50}$ ekstrak daun tua dan daun muda tumbuhan lidah mertua yang diperoleh, dapat diketahui bahwa $\mathrm{IC}_{50}$ asam askorbat 65,433 ppm. Hal ini menandakan bahwa sifat antioksidan senyawa bioaktif yang terkandung dalam ekstrak daun tua dan daun muda tumbuhan lidah mertua bersifat sedang, dan memiliki aktivitas antioksidan yang baik jika dibandingkan dengan asam askorbat. Suatu senyawa dikatakan memiliki aktivitas antioksidan yang baik, apabila nilai $I_{50}$ kurang dari 200 ppm. Apabila suatu senyawa memiliki nilai $I_{50}$ di atas 200 ppm sampai 1.000 ppm, maka dapat dinyatakan bahwa senyawa tersebut masih memiliki potensi sebagai antioksidan, namun aktivitasnya kurang baik (Widianingsih, 2016).

Sampel dinyatakan sebagai antioksidan sangat kuat jika nilai $\mathrm{IC}_{50}<50$ ppm, sebagai antioksidan kuat jika nilai $I_{50} \quad 50-100$ ppm, sebagai antioksidan sedang jika nilai $I_{50} 100-150$ ppm, sebagai antioksidan lemah jika nilai $I_{50}$ 151-200 ppm dan dinyatakan tidak aktif jika mempunyai nilai $I_{50}>200$ ppm. (Artanti \& Lisnasari, 2018). Kestabilan antioksidan dapat dipengaruhi oleh beberapa faktor, yakni suhu, perubahan $\mathrm{pH}$, sinar dan oksigen, serta faktor lainnya, seperti ion logam. Selain itu, proses analisis tidak langsung dilakukan saat ekstrak kental telah siap, sehingga kondisi dan masa penyimpanan sampel menyebabkan senyawa fenol yang diduga terdapat di dalamnya mengalami degradasi. Selain itu, ada pula faktor yang mempengaruhi zat aktif pada tanaman, yaitu kandungan unsur hara pada tanaman (Sari \& Ayati, 2018).

\section{KESIMPULAN}

Hasil uji fitokimia ekstrak daun tua dan daun muda tumbuhan lidah mertua mengandung senyawa flavonoid, alkaloid, dan saponin. Nilai $\mathrm{IC}_{50}$ ekstrak daun tua dan daun muda tumbuhan lidah mertua masing-masing diperoleh sebesar 131,336 ppm dan 144,568 ppm. Kedua ekstrak ini tergolong antioksidan bersifat sedang.

\section{UCAPAN TERIMAKASIH}

Penulis mengucapkan terima kasih kepada Kepala Laboratorium Kimia FKIP Universitas Tadulako, Kepala Laboratorium Penelitian Jurusan Kimia FMIPA Universitas Tadulako, serta semua pihak yang telah membantu penulis dalam penyelesaian penelitian ini. 


\section{DAFTAR PUSTAKA}

Achmad, S.A. (1986). Buku materi pokok kimia organik bahan alam. Jakarta: Karunika Jakarta Universitas Terbuka.

Arifin, B. \& Ibrahim, S. (2018). Struktur, bioaktivitas dan aktivitas antioksidan flavonoid. Jurnal Zarah, 6(1): 21-29.

Artanti, A. N. \& Lisnasari, R. (2018). Uji aktivitas antioksidan ekstrak ethanol daun family solanum menggunakan metode reduksi radikal bebas DPPH. Journal of Pharmaceutical Science and Clinical Research, 02: 62-69.

Chezem, W. R \& Clay N. K. (2016). Regulation of plant secondary metabolism and associated specialized cell development by MYBs and bHLHs. Phytochemistry, 131(1): 26-43.

Estikawati, I \& Lindawati, N. Y. (2019). Penetapan kadar flavonoid buah oyong (Luffa acutangula (L.) Roxb) dengan metode spektrofotometri Uv-Vis. Jurnal Farmasi Sains dan Praktis, 5(2): 96-105.

Hasnaeni \& Aminah. (2019). Uji aktivitas antioksidan dan profil fitokimia ekstrak kayu beta-beta (Lunasia amara Blanco). Jurnal Farmasi Galenika, 5(1): 101-107.

Hestiningtyas, B., Siallagan, J., \& Holle, E. (2019). Uji aktivitas ekstrak daun gatal (Laportea decumanum (Roxb.) Kuntze) sebagai antioksidan. AVOGADRO, 3(1): 1-5.

Ifada, R., Hermayanti, D. \& Nurhasan, Y. T. (2016). Pengaruh ekstrak daun lidah mertua (Sansevieria b Trifasciata Laurentii). Jurnal FK UNISMUH Malang, 12(2): 66-74.

Kosasih, E. \& Setiabudi, T. (2004). Peran antioksidan pada lanjut usia. Pusat Kajian Nasional Masalah Lanjut Usia.

Lombogia, B., Budiarso, F. \& Bodhi, W. (2016). Uji daya hambat ekstrak daun lidah mertua (Sansevierae Trifasciata Folium) terhadap pertumbuhan Bakteri Esherichia coli dan Streptococcus sp. Jurnal e-Biomedik, 4(1):

Mariani, S., Rahman, N. \& Supriadi. (2018). Uji aktivitas antioksidan ekstrak buah semangka (Citrullus lanatus). Jurnal Akademika Kimia, 7(2): 96-101.

Marliani, L., dkk. (2017). The effect of extraction condition on the polyphenol content and antioxidant activity of Curcuma zedoaria (Christm.) Roscoe Rhizome. IJPST, 4(2).

Masrifah, Rahman, N., \& Abram, P. H. (2017). Uji aktivitas antioksidan ekstrak daun dan kulit labu air (Lagenaria siceraria (M.) Standl.). Jurnal Akademika Kimia, 6(2): 98-106.

Molyneux, P. (2004). The use of the stable free radical diphenylpicrylhydrazyl (DPPH) for estimating antioxidant activity. J. Sci. Technol. 26(2): 211-219.
Nasution, H. \& Rahma, M. (2014). Pengujian antiradikal bebas difenilpikril hidrazil DPPH ekstrak etil asetat daun nangka (Artocapus heterophyllus Lam.). Jurnal Sains Dasar, 3(2): 137-141.

Nurhaeni, Gladys, \& Hardi, J. (2019). Uji aktivitas antioksidan ekstrak lumut hati (Marchantia polymorpha). Kovalen, 5(3): 315-321.

Prakash, A., Rigelhof, F., \& Miller, E., (2001). Antioxidant activity. Medallion Laboratories: Analithycal Progres, 19(4): 1-4.

Robinson, T. (1995). Kandungan organik tumbuhan tinggi. Bandung: ITB press.

Sagita, D., Aliyah, S. H., \& Safitri, M. (2018). Potensi lidah mertua (Sansevieria trifasciata P.) dalam menghambat pertumbuhan bakteri Salmonella Spp dan Staphylococcus Aureus. Riset Informasi kesehatan, 7(2): 129-133.

Sari, A. K. \& Ayati, R. (2018). Penentuan aktivitas antioksidan ekstrak etanol daun jeruk purut (Citrus hystrix DC) dengan metode DPPH (1,1-diphenyl-2-picrylhydrazyl). Journal Current Pharmateutical Science (JCPS), 1(2): 69-74.

Sastrohamidjojo, H. (2016). Kimia dasar. Yogyakarta: Gadjah Mada University press.

Shanmugam, S., Usha, R. V., \& Pradeep, B. V. (2018). Antioxidant activity of rhizome extract of Coleus forskohlii Briq. Asian journal of pharmaceutical and clinical research,11(11): 275-279.

Sunilson et al. (2009). Analgesic and antipyretic effects of sansevieria trifasciata leaves. $J$. Traditional, Complementary and Alternative Medicines, 6(4): 529-533.

Susana, I., Ridhay, A. \& Bahri, S. (2018). Kajian aktivitas antioksidan ekstrak batang kecombrang (Etlingera elatior) berdasarkan tingkat kepolaran pelarut. Kovalen, 4(1):16-23.

Wandita, G. A. \& Musfiroh, I. (2018). Tanaman suku Zingiberaceae yang memiliki aktivitas sebagai antioksidan. Farmaka, 16(2): 564571.

Widianingsih, M. (2016). Aktivitas antioksidan ekstrak metanol buah naga merah (Hylocereus polyrhizus (F.A.C Weber) britton \& rose) hasil maserasi dan dipekatkan dengan kering angin. Jurnal Wiyata, 3(2): 146-150.

Widiastuti. (2016). Aktivitas antioksidan dan tabir surya ekstrak etanol daun stroberi (Fragaria $X$ ananassa A.N. Duchesne). Jurnal Sains Farmasi \& Klinis, 3(1), 19-24. 